\title{
THE ROLE AND IMPORTANCE OF FORMAL ELEMENTARY EDUCATION FOR THE DEVELOPMENT OF ENTREPRENEURIAL ABILITIES IN ACCORDANCE WITH THE ETHICAL PRINCIPLE
}

\author{
Aleksandra Manić ${ }^{1}$, Svetlana Trajković ${ }^{2}$ \\ 1"Dositej Obradovic" School, Vranje, Republic of Serbia \\ ${ }^{2}$ The College of Applied Professional Studies, Vranje, Republic of Serbia \\ saskasrbija@gmail.com, cecasvtr@yahoo.com
}

\section{Original Scientific Paper doi:10.5937/jouproman7-21339}

\begin{abstract}
Education means an organized activity of transferring and acquiring knowledge, with the development of certain abilities and skills, and the formation of working and living attitudes. Historically, this activity is as old as humanity, evolving in parallel, with socio-economic development, in order to grow into a particularly important activity, important for every social community. Investing in people's education appears as an important driving resource, forms the basis of society's development and is part of the development strategy of all developed countries. The most important form of entrepreneurship manifestation is through the economic context, where the measure of success, the readiness of entrepreneurs to rapid changes, caused by modern business conditions, for which the most important is pre-school education. Entrepreneurship and entrepreneurial education have never been more important, especially if the number of unemployed younger age groups is taken into account. The overall effectiveness of entrepreneurship, whether self-employed or group entrepreneurship, requires, besides general conditions and psychic characteristics of entrepreneurs, a significant level of entrepreneurial education, so education for entrepreneurship must be taken as a very important component in the development of entrepreneurship. Entrepreneurial education should be treated as a production investment, and not as consumption, because the education of accumulation of capital, and for this reason, should begin with education at an earlier age, through formal education. Using natural resources, in order to improve their own quality of life, man has broken the natural balance and created a series of
\end{abstract}

problems. It paradoxically caused counter effects, but also influenced the change of perception. Namely, the anthropocentric approach to nature must be replaced by biocentric, which makes nature and its laws closer to all human spheres. This requires a special approach to entrepreneurship, in accordance with the principles close to nature, in the earliest period of life through formal primary education.

Key words: entrepreneurship, education, primary education, ecological culture

\section{Introduction}

Homo sapiens first began to confront nature and to change against her will, which caused devastation of the environment. Every society reproduces its environment as an expression of its way of life. Environmental problems have arisen as a consequence of the level of development of social relations and the way of production and relations towards the use of natural resources. Ecological entrepreneurial education becomes a prerequisite for social development, but also the survival of the society as a whole. Education, as a longterm process, but also as a basic human right, is conditioned by social educational conditions and policies, but also by the specific characteristics of individuals. 
Entrepreneurial education can be viewed in a narrower or wider context. In the strict sense, it means training individuals, entrepreneurs, for a certain business activity. The wider context implies the development of entrepreneurial spirit, entrepreneurial behavior and entrepreneurial abilities, as well as the acquisition of appropriate entrepreneurial knowledge, and does not necessarily involve dealing with business activity or entrepreneurial business.

The development of entrepreneurial spirit begins in elementary school through the development of entrepreneurial attitudes of students. The main emphasis on entrepreneurial learning at the elementary school level should be student motivation (from the first grade) to use their creativity and research and experiment with new approaches to the educational process. Active forms of learning, students should be encouraged to gain knowledge about the local community in which they live and develop interests for the activities that take place in it.

\section{Entrepreneurship - a phenomenon of the modern era}

The notion of entrepreneurship and entrepreneurs is very often used and widely distributed in almost all fields of human activity. For this reason, there is a very large number of different definitions of this phenomenon. Penezic ${ }^{1}$ recognizes entrepreneurship in any business sector and type of business. It is necessary for selfemployment, in companies of any size and at all stages of the company's life cycle. Entrepreneurship is a specific and original

\footnotetext{
${ }^{1}$ Penezić, N., 2009. Preduzetništvo, savremeni pristup. Novi Sad.
}

business or business that arises by finding and exploiting market opportunities and opportunities or by spotting problems in the consumption system and by solving them in a different, different and better way than those used and known. "2

An Entrepreneur is a person who, by applying a new idea or innovation and taking over business risk, places the products / services on the market in order to obtain a profit. Therefore, pedestrian behavior is imperative in the employment of the youth population.

We witness the fourth industrial revolution that dictates new ways of doing business. In the past, three historical events have changed the world. The first is the transition from manual to machine production between 1760 and 1840, using a steam engine. The second event allowed mass production around 1850 and brought electricity, as well as the use of oil as the most important source of power in the world. The third, digital revolution, occurred in the middle of the 20th century, and was caused by the arrival of electronics and information technology and telecommunications. The fourth industrial revolution, continues on the previous three and brings with it a great development opportunity. Basically, it is based on total automation of production, and involves switching to new systems. It was launched by a high-tech project, the German government, in 2013, with the aim of bringing production to a stage of total independence from man. It changes the nature of life and work from the root. Many jobs and occupations will simply disappear.

\footnotetext{
2 Jovanović-Božinov, M., Živković, M., Langović, A., Veljković, D., 2004., Preduzetništvo, Megatrend univerzitet primenjenih nauka, Beograd.
} 
All this brings with it a series of questions and dangers, but also opportunities and chances.

In such turbulent, cruel business conditions, people with their intellectual and creative potentials represent the strategic development base of every society. Human capital, as a base of ideas, knowledge and information, appears as a key factor of success and a crisis management factor, while in such business conditions, new professions are created by entrepreneurs.

Entrepreneurship, besides, ideas and knowledge, make the corresponding characteristics of the entrepreneur. Key characteristics of the entrepreneur's personality are:

- initiative and innovation

- self-esteem,

- self-confidence,

- independence,

- willingness to take risks,

- intelligence,

- creativity,

- energetic ...

Despite possessing such characteristics of personality, most people are not entrepreneurs, so far the activation mechanism of the "entrepreneurial gene" has not been established. It is estimated that around $3-5 \%$ of people have a talent for entrepreneurship, regardless of their education. Studies by Harvard University and the Massachusetts Institute of Technology have found that entrepreneurs often have "more than average success in their previous jobs" ${ }^{3}$. When there is a problem of low preference for entrepreneurship with high social opportunities for entrepreneurship, policies and programs need to be designed in order to improve the socio-economic dimension of the environment. In the short term, it can be fairs and various activities to reward entrepreneurial efforts, while long-term policy implies the inclusion of the value of entrepreneurship in the country's education system (Aruwa, 2008).

No interest is certain. The basis for the future is the education of young people, who will be ready to constantly look for opportunities, examine the environment, look for problems and adequate solutions for them. The future belongs to young entrepreneurs. Entrepreneurship is a state of consciousness, a much more attitudes about life than skills or professions, and for that reason should start with education as soon as possible.

\section{Educational system in Serbia}

Education has enormous significance for individuals and societies in which it is realized. Historically, it had different meanings, from the "harmonious education of an individual" in Germany to idealistic philosophy, through nobleness and humanity, to education in terms of training for life, through knowledge, skills and habits.

In a wider sense, it represents a constant process of achieving spiritual values, a lifelong process, and aims to "raise the awareness of the participants in the educational process about the importance and importance of taking responsibility for one's own destiny, leaving the philosophy of" getting a job "and accepting the philosophy of" in the development and promotion of entrepreneurial qualities

\footnotetext{
${ }^{3}$ Siropolis, N.C., Small Business Management: AGuide toEntrepreneurship, Houghton Misflir, 1990., str.42.
} 
(creativity, recognition of business challenges and opportunities in the environment, risk taking, flexibility and flexibility, perseverance and persistence, orientation towards activities, responsibility with achieved as a result of a way of life. "4

The educational process includes all segments of life, does not begin or end with education. It shares formal, non-formal and informal education. Percentage distribution of individual forms of education is an individual category and it is different at different times of life. The essence of the educational process is in linking and complementing formal, non-formal and informal education, through the individual development and shaping of each individual. On the quality educational process, as a whole, not only the individual characteristics of students and teachers are affected, but also the characteristics of the family and the overall social environment.

\begin{tabular}{|l|l|l|}
\hline \multicolumn{3}{|c|}{ EDUCATION } \\
\hline FORMAL & NEFORMAL & INFORMAL \\
\hline PRESCHOOL & TRAININGS & EXPERIENCE \\
BASIC & COURSES & \\
MIDDLE & CONFERENCES & \\
HIGH & SEMINARS & \\
& FAIRS ... & \\
\hline
\end{tabular}

Table: Types of education

Formal education implies different educational processes that occur within the formal education system, which are clearly hierarchically defined (from elementary schools to faculties), and as their ultimate goal is the acquisition of certain titles and diplomas. Formal education is therefore often called "certified education" (Kulic, 2002). The educational system is under the jurisdiction of the Republic of Serbia - the Ministry of Education, Science and Technological Development, and a smaller part of the tasks are under the responsibility of the Secretariat for Education and Child Care.

\footnotetext{
${ }^{4}$ Paunović, S. (2009). Preduzetničko obrazovanje - kako ga učiniti efikasnijim i preduzetnijim?, Singidunum revija, 5(2), pp. 144-149
} 


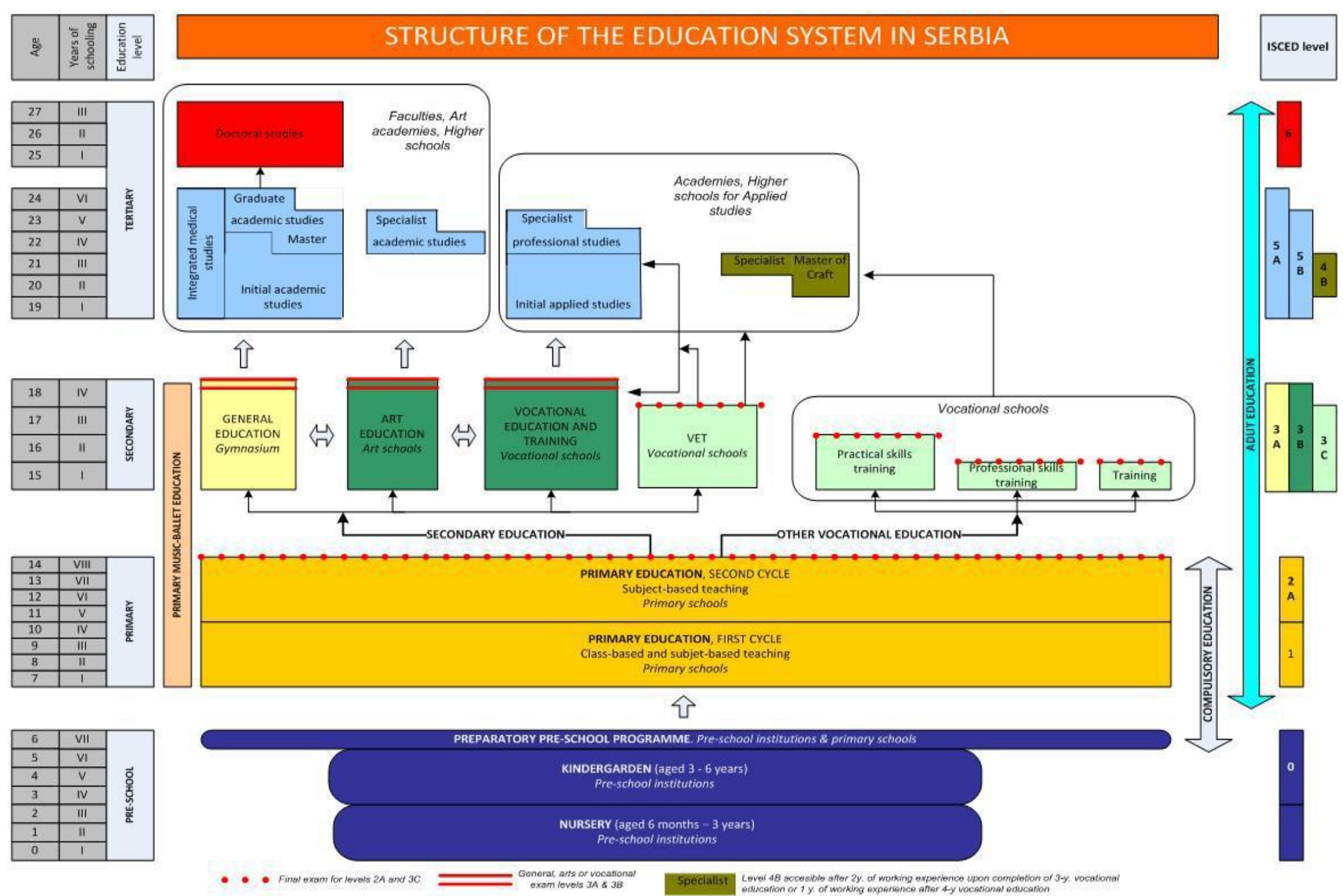


The basis for the model of the education system of a state is the existing market mode of business, which is causally connected with entrepreneurship. The most important effect and profit that the community generates in the activities of entrepreneurs are healthy companies that are leading the way in the development of new, innovative technologies which, above all, the quality of their products and services, have a progressive influence on the social community ${ }^{5}$.

\section{Entrepreneurial education \\ Entrepreneurial education is}

expected to enable the development of personal qualities and attitudes that will enable entrepreneurial approach to work and community activities, as well as the development of specific knowledge and skills, for the realization of ideas in concrete activities. It is known that the education and performance of an individual are in a high correlation. Similarly, the business success of entrepreneurs depends to a large extent on his entrepreneurial education, which is especially true for entrepreneurs in developed countries, because their work effects are largely conditioned by the entrepreneurial knowledge they possess.

Entrepreneurial education is a continuous process that enables the development of necessary knowledge and the effective launching and management of new ventures (Politis, 2005). The effectiveness of entrepreneurial education, as a special segment of the overall professional education, condition the same principles as the whole of education.
In the Oslo Agenda for Entrepreneurship Education in Europe ${ }^{6}$, Member States are recommended to integrate programs and activities that strengthen entrepreneurial competencies in existing curricula. Recommendations include the integration of entrepreneurship as a horizontal element in all teaching subjects at ISCED level 1 and level 2 (frame equivalent of our primary school), or as a special subject, at higher levels of education. According to the Global Entrepreneurship Monitor (GEM) Special Report 2008, entrepreneurial education is broadly defined as building knowledge and skills "o" or "for" entrepreneurship in general, as part of recognized education programs in educational institutions, primary, secondary and tertiary training. The goal of entrepreneurial education in primary schools are not the creation of competences of business people, but the formation of an entrepreneurial proactive way of thinking, while promoting creativity, innovation and self-reliance.

At the EU level, it is a priority for all Member States to include at least one practical entrepreneurial activity in compulsory education, as outlined in the "Action Plan for Entrepreneurship 20207" and the Publication of Reflections on Education ${ }^{8}$. "Entrepreneurial education in the early stages of education - from lower to upper grades of elementary school provides the basis for attending the teaching of entrepreneurship as a special subject in later years, ie in secondary education and further"."

\footnotetext{
${ }^{5}$ Ivković D., Čukanović-Karavidić M., Kvrgić G., Preduzetništvo kao faktor privrednog rasta i razvoja, Trendovi u poslovanju, Kruševac, 2013, naučno stručni članak, str. 56.

6 Evropska komisija, Oslo agenda za preduzetničko učenje u Evropi (Brisel 2006)

${ }^{7}$ Evropska komisija, 2013a

${ }^{8}$ Evropska komisija 2012a
}

\footnotetext{
${ }^{9}$ McCoshan, A. et al, 2010. Towards Greater Cooperation and Coherence in Entrepreneurship Education. Report and Evaluation of the Pilot Action High Level Reflection Panels on Entrepreneurship Education initiated by DG Enterprise and Industry and DG Education and Culture. [pdf] Available at: http://ec.europa.eu/enterprise/policies/s me/promotingentrepreneurship/education-training-entrepreneurship/ reflectionpanels/files/entr_education_panel_en.pdf
} 
Following the introduction of the amendments to the Law on the Basics of the Education System 2009, the education system in Serbia was enriched by an entrepreneurial approach. At the level of elementary education, entrepreneurial learning is focused on the development of individual quality students that contribute to the development of an entrepreneurial attitude. In this educational period, students should develop autonomy and proactivity, as well as to become familiar with the way of work and business. Activities that encourage active learning at this age are project work, learning through play, presentations of simple case studies and visits to local businesses and institutions. The law prescribes training for work and profession through the creation of professional competencies, in accordance with the requirements of the occupation and the needs of the labor market and training for making valid decisions on the choice of further education and occupation, their own development and future life (Article 4). From school year 2018/19. In Serbia, in the curriculum of the subject General Education, entrepreneurship education for the students of the 1st and 5th grade of the elementary school was included. Standards for evaluating the quality of education in the field of entrepreneurship are defined, not through a specific subject, but at the level of elementary and secondary schools as a whole, because they expect the cooperation of a large number of teachers from different subjects, and a special approach to a specific problem.

\section{Primary school}

The student recognizes the possibility of turning ideas into activities. Creativity, self-awareness and ingenuity develop, it moves to accept change, take responsibility and clear orientation towards achieving goals and achieving success.

A student through education acquires awareness of his own potentials and interests and is able to independently choose a future career and path of his professional development.

Realizes pre-conceived ideas and participates in projects related to schools and local communities.

Educational institutions should inform pupils about how small and large companies operate and how to start new businesses. They should encourage those who are learning to search for reasons that explain why some companies succeed, and they do not succeed.

The student acquires knowledge about the characteristics of certain jobs and jobs, understands the world of work and business from the perspective of society and is ready for volunteer work and the launch of humanitarian actions Entrepreneurial projects give students the opportunity to practice all the necessary skills within a carefully designed practical activity.

- $\quad$ Adapted to social and economic changes, is focused on the development of new skills that apply in practical work; faces uncertainties in an incredible way.

- $\quad$ Recognizes your own strengths and opportunities in relation to future education and professional orientation.

- Ready to participate in independent and team projects; is capable of developing an idea, presenting, explaining and negotiating with the team about its realization; participates in activities with others within their team role.

- $\quad$ He is motivated and able to point out his good qualities that are important for the performance of school and work assignments and uses CV and motivation letter to describe his competencies, desires and expectations.

- He knows how to set realistic goals and, based on the given possibilities, can plan and find ways to achieve them

Table: Competence, entrepreneurship and orientation towards entrepreneurship in elementary school (Source: Institute for the Evaluation of the Quality of Education, 2013, page 3) 
The competencies that students acquire after primary and secondary school for work and lifelong learning are: (1) competence for lifelong learning, (2) communication, (3) data and information work, (4) digital competence, (5) solving problems, (6) cooperation, (7) responsible participation in a democratic society, (8) responsible attitude towards health, (9) responsible attitude towards the environment, (10) aesthetic competence, (11) entrepreneurship and entrepreneurship orientation (Evaluation Office quality of education and upbringing, 2013, page 3).

\section{Entrepreneurial education based on ecological culture}

By improving the quality of his life, man destroyed natural resources and caused the destruction of the natural balance. This has disrupted nature and created a problem for itself, which is now affecting the quality of his life. Creating an ecological culture and a biocentric approach is now imposed as a necessity. Ecological culture represents an ecological view of the world and basically contains ecological knowledge. Ecological culture must be a key segment of entrepreneurial formal education in elementary schools. Within the competences acquired after primary and secondary school, a responsible attitude towards nature is expected, but it is only a segment of ecological culture. The utilitarian attitude towards nature, which was dominant, must be overcome. Environmental problems are solvable only by the change of consciousness and access, because they are caused by inadequate human behavior and thinking.

\begin{tabular}{|l|l|}
\hline Values & Norms and behaviors \\
\hline Environment and natural resources & $\begin{array}{l}\text { Responsible and planned protection of the } \\
\text { environment and nature; responsible management of } \\
\text { natural resources, conservation of biodiversity, use of } \\
\text { renewable energy sources and energy efficiency, } \\
\text { waste management and the like. }\end{array}$ \\
\hline Human Rights and Democracy & $\begin{array}{l}\text { Building a democratic society with respect for } \\
\text { nonviolence, peace and tolerance. Respect for human } \\
\text { rights and equality, security, ethical standards, global, } \\
\text { national and local responsibilities, civic dialogue and } \\
\text { the like }\end{array}$ \\
\hline Social cohesion & $\begin{array}{l}\text { Social work, better quality of life, social responsibility } \\
\text { and solidarity. }\end{array}$ \\
\hline Health & $\begin{array}{l}\text { Information and education on disease prevention, } \\
\text { healthy lifestyles, high-quality and affordable public } \\
\text { health and the like. }\end{array}$ \\
\hline Cultural and traditional heritage & $\begin{array}{l}\text { Development of cultural identity, understanding and } \\
\text { protection of the intangible and material cultural goods } \\
\text { and the like. }\end{array}$ \\
\hline $\begin{array}{l}\text { Socially responsible business, sustainable production } \\
\text { and consumption, transparency in } \\
\text { business, } \\
\text { information and consumer rights, principle of efficient } \\
\text { use of resources, principle of limited use and } \\
\text { substitution, principle of green public procurement, } \\
\text { issuing certificates, organic production and the like. }\end{array}$ \\
$\begin{array}{l}\text { Local, regional, rural and urban development and the } \\
\text { like. }\end{array}$
\end{tabular}

Table: Areas of action of ecological culture 
Ecological culture, as a wider concept, is based on the values of life and responsibility, presupposes competence and clearly defined processes of acquiring and applying knowledge and skills. It is again gaining importance due to the long-standing indifference of society and avoiding a global ecological crisis that has no end (Skenderovic et al., 2013). Ecological culture at the very beginning has the preservation of the natural environment as its value and the value of an individual as a subject of environmental protection. At the same time, ecological values are basic educational values: responsibility, identity, respect for diversity, solidarity, equality. Ecological values are both the value of life and the right to life, interactive coexistence and tolerance (Lai, 2005). Education with the strengthening of ecological competencies requires a new approach to the educational process, new learning strategies and an interdisciplinary approach to early-school education through formal education with a particular emphasis on formal education for entrepreneurship. Technological advancement and globalization shape workplaces and business conditions, and it is therefore important that future generations are equipped with the skills and thoughts that will be needed in the business world, whose direction of development is impossible to predict. .

Entrepreneurial learning according to the principles close to nature is based on four key segments:

- application of modern teaching methods,

- $\quad$ strengthening entrepreneurial

competences (through teaching and extracurricular activities),

- strengthening of ecological culture,
- Cooperation with schools with local community (enterprises, organizations and institutions).

Formal entrepreneurial education in primary schools should provide the basis for an ecological view of the world with a critical assessment of environmental and economic relations. Entrepreneurship is a process of creating economic values by combining risk, creativity and innovation. The personal characteristics and attitudes of a particular educational institution should create an environment that encourages students to ask questions and seek new approaches through an interactive relationship with business and entrepreneurs, along with their ecological culture.

\section{Conclusion}

We live on a planet that promotes life, but on the other hand it extinguishes it. The key to survival on Earth is the readiness for constant change in line with changes that occur in nature. Entrepreneurial society requires entrepreneurial learning based on ecological values and principles. All this requires new learning strategies, but also new competencies. Primary education should include an introduction to the economic economy through getting to know the world of work, through meetings and conversations with people of different occupations, as a basis for entrepreneurial thinking and creation of entrepreneurial competences, while at the same time raising ecological culture as a wider segment which implies not only sustainable production, consumption and development, but also respect for cultural heritage, social cohesion, people and democratic processes. 
They should be encouraged to develop ideas and take on social responsibility. They should be given the opportunity to actively participate in entrepreneurial activities through entrepreneurial clubs, giving them the opportunity to increase their interest in entrepreneurship, but also to strengthen team spirit and social responsibility as segments of the ecological culture. Formal education relies on the competencies of teachers. The practice has shown that students need support, as well as additional training to meet the challenges of the new curriculum and interactive modern educational approach. Entrepreneurship, as a teaching subject, does not give answers, but allows students to ask the right questions and seek solutions. This approach, with the encouragement of ecological culture, will disable the harmful consequences of the global business of multinational companies, live on the ground as a whole and enable business security.

\section{LITERATURE}

1. Aruwa, S., 2008. Entrepreneurial Factors and the Development of Entrepreneurship inAfrica. [Online] Available at: HYPERLINK

http://www.academia.edu/260381/Entrepre neurial_Factors_and_the_Development_of _Entrepreneurship_In_Africa

2. Evropska komisija, Oslo agenda za preduzetničko učenje u Evropi (Brisel 2006)

3. Evropska komisija, Akcionom planu za preduzetništvo 2020

4. https://media.anlaufstelleanerkennung.at/Spasenovic_BKS.pdf

5. Ivković D., Čukanović-Karavidić M., Kvrgić G., Preduzetništvo kao faktor privrednog rasta i razvoja, Trendovi u poslovanju, Kruševac, 2013, naučno stručni članak

6. Jovanović-Božinov, M., Živković, M., Langović, A., Veljković, D., 2004.,
Preduzetništvo, Megatrend univerzitet primenjenih nauka, Beograd

7. Kayanula, D. \& Quartey, P. (2000), The policy environment for promoting small and medium-sized enterprises in Ghana and Malawi, IDPM Finance and Development research programme working paper series 15.

8. Kulić, R., 2002., Formalno, neformalno I informalno učenje I obrazovanje, Andragoške studije

9. Lay, V. (2005). Integralna održivost i učenje. Društvena istraživanja

10. McCoshan, A. et al, 2010. Towards Greater Cooperation and Coherence in Entrepreneurship Education. Report and Evaluation of the Pilot Action High Level Reflection Panels on Entrepreneurship Education initiated by DG Enterprise and Industry and DG Education and Culture. [pdf] Available at: http://ec.europa.eu/enterprise/policies/s me/promoting-entrepreneurship/educationtraining-

entrepreneurship/reflectionpanels/files/entr _education_panel_en.pdf

11. Paunović, S. (2009). Preduzetničko obrazovanje - kako ga učiniti efikasnijim I preduzetnijim?, Singidunum revija, 5(2)

12. Penezić, N., 2009. Preduzetništvo, savremeni pristup. Novi Sad.

13. Politis, D. (2005), The process of entrepreneurial learning: A conceptual approach, Entrepreneurship Theory and Practice, Vol. 29, No. 4.

14. Skenderović, I., Kalač, B., Elfić, E., Tutić, A. (2013). The role of environment education in protecting and

15. improving the living environment. Ekonomika. 59 (3),

16. Siropolis, N.C., Small Business Management: A Guide to Entrepreneurship, Houghton Misflir, 1990. 